\title{
COFFEE CERTIFICATION PARTICIPATION AND ITS IMPACT ON SMALLHOLDER FARMERS' INCOME IN JIMMA ZONE, SOUTHWESTERN ETHIOPIA
}

\author{
Yadeta Bekele Bekere $^{1 *}$, Guta Regasa Megersa ${ }^{2}$ \\ ${ }^{1}$ Department of Agricultural Economics and Agribusiness Management, Jimma University Ethiopia \\ ${ }^{2}$ Department of Rural Development and Agricultural Extension, Jimma University, Ethiopia \\ *correspondence: yadeta11@gmail.com
}

\begin{abstract}
Certification is an instrument to add value to a product, and it addresses a growing worldwide demand for healthier and more socially and environmentally friendly products. Globally, coffee certification has received strong recognition as it is proved to increase smallholder farmers' access to input and output markets, production, productivity and income. This study investigates the major determinants of coffee certification participation. It also analyzes the welfare gains of participation in the certification schemes by smallholder coffee growers. Both primary and secondary data were used. Primary data were collected from randomly selected 247 coffee producers. Structured questionnaires, focus group discussions and key informant interviews were employed to collect the primary data. Descriptive statistics and econometric models were used for data analysis. Probit model was used to identify factors affecting participation in coffee certification schemes. Propensity score matching technique was used to estimate the impact of coffee certification participation on smallholders' annual revenue from coffee production. The probit model result revealed that access to training, family size, land size owned, experience in coffee production, education status were significantly determined the smallholders farmers' participation decision in coffee certification. The propensity score matching model result also shows that participation in coffee certification significantly $(\mathrm{p}=0.001)$ improved farmers' annual revenue by 2,902 Ethiopian birr compared to selling coffee without the certification schemes. This income impact is mainly attributed to the premium price the certification offer to farmers for high quality coffee. Therefore, policies or projects related to coffee value chains should target improving farmers' access to training, boosting the access to education, working on farmers' productivity and increasing their technical knowhow on coffee certification to increase farmers' participation in coffee certification and to improve their annual revenue earning level in the study area.
\end{abstract}

Keywords: Certification, Coffee, Impact, Income, Propensity score matching, Smallholder farmers

http://dx.doi.org/10.21776/ub.agrise.2021.021.2.2

Received 24 December 2020

Accepted 29 April 2021

Available online 30 April 2021

\section{INTRODUCTION}

Coffee is one of the most important beverages in the world. Ethiopia is the origin of Coffee Arabica (Coffea arabica L.) and the largest producer of coffee in Africa and the fifth largest coffee producer in the world (GAIN, 2014). Smallholder coffee farmers, increased their coffee production by $50 \%$ over the past two decades (ICO, 2019).

Literatures confirm that Ethiopia is the homeland of genetic diversity of Arabica coffee
(Coffea arabica L., Rubiaceae) (Vavilov, 1951). The scholars estimated that Ethiopia hosts about 40,000 wild varieties of coffee. Coffee is mainly produced in the Southern, South Western and Eastern parts of the country.

Coffee contributes about 30 percent of the country's foreign currency earnings in Ethiopia. In Ethiopia more than 15 million people directly or indirectly depend on coffee value chain for their income and employment. About 35\% of the total production is consumed within the producing areas 
and in general and over $50 \%$ of the coffee produced is consumed within the country (CSA, 2017).

The area coverage of coffee in Ethiopia is estimated to be around 764863.16 ha produced by 5.12 million small-scale farm households (CSA, 2019).

Certification is an instrument to add value to a product, and it addresses a growing worldwide demand for healthier and more socially and environmentally friendly products. It is based on the idea that consumers are motivated to pay price premia for products that meet certain precisely defined and assured standards (Ponte, 2004). These price premia can help internalize environmental costs of the product by supporting more sustainable production, processing and marketing. However, price premia can also promote incentives that lead to unwanted effects (Grote, 2009).

Certification is a voluntary and marketdriven approach by which products are assessed and confirmed to meet the stated requirements. It is based on the idea that consumers are willing to purchase a relatively more expensive certified product. The analysis of the effects of certification on smallholder farmers can be subdivided in to five dimensions of livelihoods namely access to education and training, working conditions, gender equality and access to market information (Grote, 2009). In the study area, coffee is certified based on its quality. It is also certified whether it is organic or not.

Producers' benefits of certification are related to price premia, improved market access, longer-term supply contracts that may lead to stronger relationships between buyers and suppliers and/or increased productivity in management. Costs refer to the initial costs of investing in to organizational and technical infrastructure as well as knowledge and labor needed to meet certain requirements, but also to the recurrent costs of certification.

As a result, increased income from certified coffee may not necessarily equate to increased income for the household. Even coffee-specific income will be dependent on many factors, including farm-gate price, yield, and costs of production, such that increased farm-gate prices may not necessarily result in increased revenue if yields decline or production costs increase to a greater extent. Some case studies found household revenue increasing between $12 \%$ and $20 \%$ because of certification (Ruben \& Fort, 2012).

The impact of coffee certification on the income of the producers was assessed in this study. The certified coffee producers and uncertified ones were compared based on their access to market linkages, and access to other institutional supports. Agricultural development policy of Ethiopia is designed to support market-led agricultural development. However, competitiveness of smallholder producers and commercialization of small-scale production depends on the development of viable market linkages, which the policy actions still lack to address mostly at the smallholder level.

The capacity of smallholder farmers to produce the required quality and quantity as per buyers' demand is not well developed due to imperfect market systems. Certification could encourage increased production, productivity and quality of agricultural production.

Therefore, the relevance of this study is linked to the perspective that coffee certification bring about improvements in the value chain, and ease ways of information sharing and diffusion. By doing so, it contributes to increased share of the market benefit to farmers and ultimately contributes to poverty reduction through income improvement and domestic partnership improvement at the end of the day.

In Ethiopia farmers face different major problems related to production and marketing. First, they do not have full information about what quality and quantity is demanded in the market and what prices are being paid for their crop in regional markets. Second, farmers do not have access to warnings about risks that could damage their crops. Third, due to poor infrastructures, extension workers could not reach all the farmers to train them in production techniques and the farmers could not bargain on transportation costs. Improving the position of farmers in value chains requires ensuring that farmers get reliable market information on the quality and quantity demanded prices, delivery time and place. This can be done through certification.

The intention transforming subsistence agriculture towards commercialization, which is 
incorporated in Ethiopian GTP II (Growth and Transformation Plan II), can be achieved by integrating smallholder farmers to higher markets using different marketing schemes like certification participation. Therefore, this study can be used as a complement for the country's policy on commercialization of smallholder farmers.

Coffee certification addresses a growing worldwide demand for healthier and more sociallyand environmentally-friendly products based on the idea that consumers are motivated to pay a price premium for products that meet certain precisely defined and assured standards (Grote et al., 2007; Wissel et al., 2010). Being able to label a product as 'organic' or 'Fair-trade' and to protect the label from counterfeiting is considered a valuable marketing advantage in today's consumer markets. The price premiums are intended to promote socio-economic change. In this context, voluntary product certification standards are promoted as critical devices to make small-scale farmers in developing countries less vulnerable to volatile market prices and to enhance their market integration in order to increase their socio-economic situation. Therefore, this study has policy implications of producing quality coffee through certification for international markets. Integrating small-scale farmers to different markets through certification enable them to harvest high price premium. There is also climate change implication through forest conservation and gender equality due to coffee certification.

Policy makers can use the finding of this study. Policy relating to agricultural commercialization and upgrading of small-scale farmers by integrating them to fair markets shall get due attention in the area.

\section{MATERIALS AND METHODS}

\section{Description of the study area}

This study was conducted in southwestern Ethiopia, Jimma zone, Gera and Shabe districts. The area is one of the major coffee growing zones in Ethiopia. According to the Jimma zone Agricultural and Rural Development Office, coffee production in Jimma covers more than 20 percent of the total coffee export share of Ethiopia. The same source indicated that an estimated 30-45 percent of the population in Jimma is directly or indirectly engaged in coffee production, coffee processing and coffee marketing. Coffee production in Jimma is dominated by smallholder farmers following traditional extensive agro-forestry systems. Coffee produced in the area is known as 'Arabica', an internationally well-recognized brand currently fetching premium prices.

This study analyzed the integration of smallholder farmers into markets through coffee certification. Factors determining the participation of smallholder coffee producers in coffee certification were identified. The impact of coffee certification on the annual coffee revenue of the smallholder farmers was also estimated analyzed.

\section{Sampling procedures}

The target population of the study was all coffee producing smallholder farmers in Gera and Shabe districts. A multistage sampling technique was employed to select the representative respondents. In the first stage, Gera and Shabe districts were selected purposively based on their potential of coffee production and the availability of coffee certification practices. The sampling frame of participants and non-participants in certification was obtained from coffee cooperatives and from agricultural office of the district. In the second stage, smallholder farmers were stratified as certification participants and nonparticipants based on the information from coffee cooperatives. Therefore, both participant and nonparticipants of coffee certification were purposively included in the sample. A good comparison group should come from the same economic environment and by administering the same questionnaire by employing similarly trained interviewers both for the treatment group (participant) and the non-treatment group (non-participants) (Baker, 2000).

Finally, 250 respondents (from which 3 questionnaires were discarded) were randomly selected from each stratum (131 certified and 116 uncertified respondents).

\section{Methods of data collection}

Both qualitative and quantitative data were collected. Participatory approach was used which employ both the researchers and the smallholder farmers to collect the required information. Coffee 
cooperatives and agricultural development offices were involved in this study.

Primary data were collected from sample respondents of certified and uncertified coffee farmers through structured questionnaire. To supplement the data, focus group discussions with additional smallholders were also conducted.

Field survey and site selection: Belete-Gera and Shabe sombo districts were selected purposively due to the presence of both coffee contract farming and coffee certification practices. List of kebeles in both districts was identified from the office of agriculture in the area. After identifying the potential kebeles, three kebeles from each district were selected randomly for this study.

Survey questionnaire: The research team prepared the questionnaires based on the objectives of the study. Both structured and semi-structured questionnaires were prepared. Before data collection, the questionnaire was pre-tested on five farmers to evaluate the appropriateness of the design, clarity and interpretation of the questions, relevance of the questions and time taken for an interview. The questionnaire covers different topics in order to capture relevant information related to the study objectives.

FGD and KIIs: Checklists for further exploration of the contract farming and coffee certification concept was prepared. Focus group discussions (FGDs) were held with five groups based on pre-determined checklists and key informant interviews (KIIs) were undertaken with selected individuals from different organizations and institutions.

Data collection: Enumerators were recruited and trained for data collection. Individual households were interviewed using the questionnaire. The researchers were continuously supervising while the enumerators were interviewing the households.

Data entry: After data collection, the data was coded and checked for error. Experts who have a certificate for data collection and data entry were recruited and trained for data entry. Data was managed using statistical software package (SPSS 20).

\section{DATA ANALYSIS}

\section{Econometric model specification}

Probit model was used to identify factors affecting participation decision of smallholder farmers in coffee contract farming and in coffee certification in the study area.

$P_{i}^{*}=Z_{i \propto}+u_{i} \quad$ Participation equation

$P_{i}=\left\{\begin{array}{l}1 \text { if } z_{i} \alpha+u_{i}>0 \\ 0 \text { if } z_{i} \alpha+u_{i} \leq 0\end{array}\right.$

Where

$P_{i}^{*}$ is a latent endogenous variable representing households' participation decision, $\alpha$ and $\beta$ are parameters of the models, $Z_{i}$ is the vector of variables explaining participation decision, $\mathrm{U} i$ are respective error terms assumed to be normally distributed, $u_{i} \sim N(0,1)$,

\section{Impact assessment approaches}

There are several approaches for evaluating impacts. These include randomized selection methods, propensity score matching, regression discontinuity design, difference-in-difference, and instrumental variable estimation methods (Abadie et al., 2004). Randomized selection method used to assess the impact of a program when participant is randomly selected for it (UNDP, 2009). The difference-in-difference is used when baseline and time series information on both participants and nonparticipants is available. The regression discontinuity design is a quasi-experimental pretest and posttest design that elicits the causal effect of intervention that is assigned using a threshold. Propensity score matching (PSM) is used when it is possible to create a comparison group from a sample of nonparticipants closest to the treated group in the absence of baseline data using observable variables. Both groups are matched based on propensity scores predicted probabilities of participation given some observed variables (Abadie et al., 2004). Propensity score matching (PSM) was used in this study because of absence of baseline data on households' participation status before and after participation in coffee contract farming and coffee certification in the area. 


\section{Propensity score matching (PSM)}

This study employed propensity scorematching model to analyze the impact of coffee certification and coffee contract faming participation on the household's annual

revenue. PSM is a non-parametric method that is widely used in the impact evaluation of different interventions (Ravallion, 2005; Heckman et al., 1998).

To estimate the average treatment effect on the treated (ATT) the following procedures were followed;

$$
\tau i=\mathrm{Yi}(\mathrm{Di}=1)-\mathrm{Yi}(\mathrm{Di}=0)
$$

Where $\tau i$ is treatment effect because of coffee certification/contract farming participation, $\mathrm{Yi}$ is the outcome (the annual revenue from coffee) and $\mathrm{Di}$ is whether rural household $I$ was participated in coffee certification/contract farming or not.

However, Yi $(\mathrm{Di}=1)$ and $\mathrm{Yi}(\mathrm{Di}=0)$ cannot be occurred simultaneously for the same individual at the same time. Based on this the position of household in the treatment either $\mathrm{Yi}(\mathrm{Di}=1)$ or $\mathrm{Yi}$ $(\mathrm{Di}=0)$ is unobserved outcome. Hence, analyzing individual treatment effect $\tau \mathrm{i}$ is difficult. Therefore, estimating the average treatment effects of the population than the individual person was very important. Among the average treatment effects, average treatment effect on treated (ATT) was one of the most commonly used in impact assessment studies and it was described as:

$$
\tau_{-} \mathrm{ATT}=\mathrm{E}(\tau / \mathrm{D}=1)=\mathrm{E}[\mathrm{Y}(1) / \mathrm{D}=1]-\mathrm{E}[\mathrm{Y}(0) / \mathrm{D}=1] .
$$

Here the outcome variable of participant households, $\mathrm{E}[\mathrm{Y}(1) / \mathrm{D}=1]$ is observed. However, the outcome variable of participant households had they not participated, $E[Y(0) / \mathrm{D}=1]$ is not observed. Hence, substituting the outcome (total annual coffee revenue of participant households had they not participated) $E[Y(0) / D=1]$, for outcome (total annual coffee revenue of non-participant households) is impossible in non-experimental impact assessment. This means, the total annual coffee revenue of households for participants and nonparticipants would differ even in the absence of participation leading to self-selection bias. By deducting $\mathrm{E}\left(\mathrm{Y}_{0} / \mathrm{D}=0\right)$ from the left and right side of the equation we can specify the average treatment effect on the treated as follows:

$$
\begin{gathered}
\mathrm{E}[\mathrm{Y}(1) / \mathrm{D}=1]=\mathrm{E}[\mathrm{Y}(0) / \mathrm{D}=1]-\mathrm{E}[\mathrm{Y}(0) / \mathrm{D}=0]=\tau \_\mathrm{ATT}+ \\
\mathrm{E}[\mathrm{Y}(0) / \mathrm{D}=1]-\mathrm{E}[\mathrm{Y}(0) / \mathrm{D}=0] .
\end{gathered}
$$

In this case, the terms in the left side are observables and the average treatment effect on treated can be determined if and only if $\mathrm{E}[\mathrm{Y}$ $(0) / D=1]-E[Y(0) / D=0]$ is zero. This occurs when there is self-selection bias. In order to resolve the selection matter in non-experimental impact studies the following two assumptions are required.

Conditional independence assumption: this indicates the outcomes are independent of treatment and conditional on (Xi). This assumption shows that the selection only depends on observable characteristics that affect both participation decision of households and the outcome variable simultaneously (Caliendo and Kopeinig, 2008).

Common support: This refers to the area in which both participant and non-participant households have propensity score values in common. The area contains the minimum and maximum propensity score of participant and non-participant groups respectively. Those observations whose propensity scores is smaller than the maximum of the minimums and larger than the minimum of the maximum propensity score values are discarded from the treatment and control groups (Caliendo and Kopeinig, 2008). That is $0<P(D=1) / X<1$. Given these two assumptions, the propensity scorematching algorithm to estimate ATT can be described as:

$$
T_{A T T}^{P S M}=E_{P(X) / D=1}\{E[Y(1) / D=1, P(X)]-E[Y(0) / D=0, P(X)]\}
$$

Where, $\mathrm{P}(\mathrm{X})$ is the propensity score calculated from covariate $\mathrm{X}$. The equation is explained as the PSM estimators is the difference between mean of outcomes over common support region.

\section{Choice of matching algorithm}

After estimation of the propensity scores, seeking an appropriate matching estimator is the major task of a researcher. The choice of matching method involves a trade-off between matching quality and its variance. Various matching estimators have been suggested in the literature. These include the nearest neighbor matching, caliper and radius 
matching, stratification and interval matching, kernel and local linear matching (Caliendo and Kopeinig, 2008). The nearest neighbor was selected in this study after comparing with the other matching algorithms.

Nearest Neighbor (NN) matching: It is the most straightforward matching estimator. In NN matching, an individual from a comparison group is chosen as a matching partner for a treated individual that is closest in terms of propensity score (Caliendo and Kopeinig, 2008). The NN matching can be done with or without replacement options. In the case of the NN matching with replacement, a comparison individual can be matched to more than one treatment individuals, which would result in increased quality of matches and decreased precision of estimates. On the other hand, in the case of $\mathrm{NN}$ matching without replacement, a comparison individual can be used only once. Matching without replacement increases bias but it could improve the precision of the estimates. In cases where the treatment and comparison units are very different, finding a satisfactory match by matching without replacement can be very problematic (Dehejia and Wahba, 2002). It means that by matching without replacement, when there are few comparison units similar to the treated units, we may be forced to match treated units to comparison units that are quite different in terms of the estimated propensity score.

A good matching estimator is that provides low pseudo- value and statistically insignificant likelihood ratio test of all regressors after matching (a matching estimator which balances all explanatory variables between both groups) (Smith and Todd, 2005) and also expected to retain relatively larger observations for evaluating the impact of an involvement (i.e; relatively large matched sample size is preferable) and one that yields statistically identical covariate means for both groups (Caliendo and Kopeinig, 2008). In particular, a rejection of the group means difference test after matching implies a good balancing of the covariates.

\section{Testing the matching quality}

One important concern that shall be taken care of while doing PSM is balancing test. Since we do not condition on all covariates but on the propensity score, it has to be checked if the matching procedure is able to balance the distribution of the relevant variables in both the control and treatment group. The main purpose of the propensity score matching is not to perfectly predict selection into treatment but to balance all covariates. While differences in covariates are expected before matching, these should be avoided after matching. The primary purpose of the PSM is that it serves as a balancing method for covariates between the two groups. Consequently, the idea behind balancing tests is to check whether the propensity score is adequately balanced. In other words, a balancing test seeks to examine if at each value of the propensity score, a given characteristic has the same distribution for the treated and comparison groups.

The basic idea of all approaches is to compare the situation before and after matching and check if there remain any differences after conditioning on the propensity score (Caliendo and Kopeinig, 2008). Rosenbaum and Rubin (1983) and Dehejia and Wahba (2002) emphasized that the crucial issue is to ensure whether the balancing condition is satisfied or not because it reduces the influence of confounding variables. The success of propensity score estimation is therefore assessed by the resultant balance rather than by the fit of the models used to create the estimated propensity scores (Rosenbaum and Rubin, 1983).

There are different approaches in applying the method of covariate balancing (i.e., the equality of the means on the scores and all the covariates) between treated and non-treated individuals.

\section{Sensitivity analysis for unobserved biases}

Propensity score matching provides an estimate of the effect of a treatment variable on an outcome variable that is largely free of bias arising from an association between treatment status and observable variables. However, matching methods are not robust against hidden bias arising from unobserved variable that simultaneously affect assignment to treatment and the outcome variable. One strategy for addressing this problem is the Rosenbaum bounds (2002) approach, which allows the analyst to determine how strongly an unmeasured confounding variable must affect selection into treatment in order to undermine the conclusions about causal effect from a matching analysis.

The bounding approach does not test the un-confoundedness assumption itself; because this would amount to testing that there are no (unobserved) variables that influence the selection into treatment. Instead, Rosenbaum bounds provide evidence on the degree to which any significant result hinge on this un- testable assumption. If the results turn out to be sensitive, the researcher might have to think about the validity of his/her identifying assumption and consider other estimation strategies.

Finally, using predicted probabilities those who were involved in the contract farming and 
certification (i.e. propensity score) match pairs was constructed using alternative methods of matching estimators. Then the impact estimation is the difference between simple mean of outcome variable of interest for involved and non-involved households. In particular, ATT was computed using the following equation.

$$
\frac{1}{K} \sum_{i=1}^{i \in T=1}\left[Y i^{i \in T=1}-Y i^{i \in T=0}\right]
$$

Where $\mathrm{k}$ is number of matched pairs.

\section{Variable selection, definition and its measurement}

Dependent variable: It is dummy having the values of 1 for contract farming/certification participant and 0 otherwise. In this study participating households are those who have participated in contract farming and coffee certification in the last three years (2017, 2018 and 2019) and non-participants are households who have not participated in both certification and contract farming.

Outcome variable: It

is a continuous variable measured in Ethiopian Birr, which is the total annual coffee revenue.

\section{Independent variables}

The literatures reviewed indicate that the independent variables that can influence households' participation decisions in coffee contract farming and coffee certification include demographic, socioeconomic and institutional factors.

Gender: It is a dummy variable, which takes up the value of " 1 " if the household head is a male and " 0 " if female. The women's lack of control over financial resources and the nature of their financial activities restrict their participation in either informal or formal institutions. Thus, in this study, gender is hypothesized as it affects participation decision in certification and contract farming negatively.

Age: It is a continuous variable measured in years. Age can considerably influences the decision making process. This influences the use of available resources in the best way to contribute for household asset improvement. In this study, age of the household head has a positive relation with participation in contract farming or coffee certification (Abdul-Jalil, 2015).

Education level: It is a continuous variable measured in year of schooling. E ducation increases farmers' ability to get and use information. Educated farmers may have the ability to analyze costs and benefits and thereby improve their livelihood. According to Tang et al. (2010) and Samuel (2010), those farmers who have better level of schooling have high chance of being participants of coffee contract farming and coffee certification.

Family size: It is a continuous variable and measured in number of family members living together in one home. Having large family size may imply that the household has enough labor supply for participation in different income generating activities like contract farming/coffee certification (Kifle et al., 2013; Roberts et al., 2017). On the other hand, Orebiyi et al. (2018) found that, large family size implies self-insufficiency in terms of food consumption because large households consume more than do small households. The expected effects of family size on contract farming/certification can be negative or positive.

Total land size: This is a continuous variable referring to the total land owned by households in hectare. Anderson et al. (2018) found that households owning large farm size have higher probability of participation in formal institutions. Hence, this variable is expected to have positive influence on the dependent variable.

Off-farm/nonfarm income: It is a continuous variable and it is measured in ETB. People with external sources of income rather than from solely farming, tend to participate more since they have high-income expectations in the future. Besides, income generated from non-farm activities can be plowed back to agriculture with an effect of increasing agricultural productivity (Roberts et al., 2017). Therefore, this variable is expected to affect the dependent variable positively.

Farming experience: It is a continuous variable and it is measured in years of farming experience. Kifle (2013) and Saqib et al. (2018) revealed that farming experience showed positive relationship with participation in marketing institutions that is, with an increase in farming experience, farmers' participation also increased. Hence, positive relationship was expected from this variable.

Frequency of extension contact: this is a discrete variable, which refers to the number of contacts with extension agents that the respondent made in the month. Farmers who have frequent contact with extension agents are expected to have more information that will influence farm households' participation in different institutions (Temesgen et al., 2018). Therefore, it is hypothesized that this variable positively influences the dependent variables.

Distance from the main road: It is a continuous variable measured in kilometers. Farmers near to main road or market have a location advantage in participating more in different social affairs (Samuel et al., 2015; Roberts et al., 2017; Djoumessi 
et al., 2018). Therefore, distance of farmers' residence from main road/market has been expected to affect farmers' participation in contract farming or coffee certification negatively.

Access to training: This is a dummy variable having the values of 1 if the respondent has participated in any training regarding contract farming/coffee certification and 0 otherwise. This variable was expected to affect the dependent variable negatively.

\section{RESULTS AND DISCUSSIONS General characteristics of the respondents}

From the results of this study (Table 1), 79 percent of the respondents were male-headed households and 21 percent of them were femaleheaded households. The mean age of the households was 45.42 years with the standard deviation of 11.03 . The mean education level of the respondents was 4.47 school grades with the standard deviation of 2.58. The mean family size of the respondents was found to be 6.06 with the standard deviation of 2.12.

Table 1: Demographic characteristics of the respondents

\begin{tabular}{llllll}
\hline Variable & Obs & Mean & Std. Dev. & Min & Max \\
\hline Age & 247 & 45.42 & 11.031 & 25 & 90 \\
Sex & 247 & 0.79 & 0.409 & 0 & 1 \\
Education status & 247 & 4.47 & 2.582 & 0 & 12 \\
Family size & 247 & 6.06 & 2.122 & 1 & 15 \\
\hline
\end{tabular}

Source: Survey result, 2019

\section{Land utilization}

In the study area, land is allocated for different crops. Coffee is the most commonly grown cash crop while maize is the second crop grown mainly for home consumption. The mean land holding of the respondents was 2.52 hectares in the study area. About 1.39 hectare of the land owned was allocated for coffee production whereas about 0.21 and 0.14 hectare was allocated for maize and teff production, respectively. In addition to the following crops, they also produce few vegetables and fruits like avocado, banana and mango on their own lands.

Table 2: Land utilization pattern of the respondents

\begin{tabular}{llllll}
\hline Variable & Obs. & Mean & Std. Dev. & Min & Max \\
\hline Total land owned (hectare) & 247 & 2.52 & 1.271 & 0.25 & 9 \\
Land allocated for coffee (hectare) & 247 & 1.39 & 1.391 & 0.25 & 9 \\
Land allocated for teff (hectare) & 247 & 0.14 & 0.386 & 0 & 4 \\
Land allocated for maize (hectare) & 247 & 0.21 & 0.206 & 0 & 1 \\
Land allocated for wheat (hectare) & 247 & 0.03 & 0.057 & 0 & 0.25 \\
Land allocated for barley (hectare) & 247 & 0.01 & 0.010 & 0 & 0.1 \\
Land allocated for sorghum (hectare) & 247 & 0.01 & 0.046 & 0 & 0.5 \\
Land allocated for Pulse (hectare) & 247 & 0.01 & 0.024 & 0 & 0.25 \\
\hline
\end{tabular}

Source: Survey result, 2019

\section{Livestock ownership}

Livestock is the other source of income and food in the study area. It is also source of power for plough and for transportation in the area. On average, the respondents owned 1.03 cows in TLU, 1.28 oxen in TLU, 0.11 sheep and 0.06 chickens in TLU in the area. In the study area, oxen are used for ploughing the cropland; cows are used for dairy purpose whereas donkeys, horses and mules are used for transportation purpose. Sheep, goats and chickens are used for both income source and food (meat and eggs). Farmers mainly consume meat and eggs during holidays and they sell otherwise for their financial needs.

Table 3: Livestock ownership of the respondents (in TLU)

\begin{tabular}{llllll}
\hline Variable & Obs & Mean & Std. Dev. & Min & Max \\
\hline Calf (number) & 247 & 0.25 & 0.26 & 0 & 1.5 \\
Cow (number) & 247 & 1.03 & 0.73 & 0 & 4 \\
Heifer (number) & 247 & 0.18 & 0.348 & 0 & 1.5 \\
Ox (number) & 247 & 1.28 & 0.893 & 0 & 4 \\
\hline
\end{tabular}




\begin{tabular}{llllll} 
Horse (number) & 247 & 0.011 & 0.121 & 0 & 1.1 \\
Donkey (number) & 247 & 0.14 & 0.293 & 0 & 1.4 \\
Mule (number) & 247 & 0.011 & 0.099 & 0 & 1.1 \\
Sheep (number) & 247 & 0.11 & 0.205 & 0 & 1.3 \\
Goat (number) & 247 & 0.007 & 0.033 & 0 & 0.26 \\
Chicken (number) & 247 & 0.06 & 0.052 & 0 & 0.39 \\
\hline
\end{tabular}

Source: Survey result, 2019

\section{Production analysis}

The smallholder farmers in the study area on average produce about 16.46 quintals annually with standard deviation of 12.78 . They produce 9.41 quintals of sundry coffee and 7.14 quintals of wet cherry coffee on average.

Table 4: Coffee production status of the respondents in 2018/2019

\begin{tabular}{llllll}
\hline Variable & Obs & Mean & Std. Dev. & Min & Max \\
\hline Total annual coffee production (Quintal) & 247 & 16.46 & 12.78 & 1 & 90 \\
Sundry coffee produced (Quintal) & 247 & 9.41 & 8.69 & 1 & 80 \\
Wet cherry coffee produced (Quintal) & 247 & 7.14 & 6.41 & 1 & 40 \\
\hline
\end{tabular}

Source: Survey result, 2019

\section{Market participation analysis}

The mean annual coffee consumption of the respondents was 0.92 quintals with a maximum consumption of 4 quintals. Farmers sold about 14.82 quintals of their coffee produced. The mean price of sundry coffee was 27.65 birr per kilogram in the area and it was about 19.08 birr per kilogram for we cherry coffee.

Table 5: Coffee market participation of the respondents

\begin{tabular}{llllll}
\hline Variable & Obs & Mean & Std. Dev. & Min & Max \\
\hline Coffee produced (Quintal) & 247 & 16.46 & 12.78 & 1 & 90 \\
Coffee consumed (Quintal) & 247 & 0.92 & 0.576 & 0.2 & 4 \\
Total coffee sold (Quintal) & 247 & 14.82 & 11.681 & 1 & 86 \\
Sundry coffee sold (Quintal) & 247 & 9.07 & 8.797 & 1 & 78 \\
Wet cherry coffee sold (Quintal) & 247 & 7.01 & 6.394 & 1 & 39 \\
Sundry coffee price (Birr/kg) & 247 & 27.65 & 2.236 & 25 & 30 \\
Wet cherry coffee price (Birr/kg) & 247 & 19.08 & 1.868 & 16 & 23 \\
\hline
\end{tabular}

Source: Survey result, 2019

\section{Income analysis}

The smallholder farmers in the area annually obtained on average about 38500.65 birr of revenue from coffee sale. On average, the farmers also obtained about 10117.45 birr from off-farm income annually. In the study area, credit utilization is not as such exploited due to religious aspects. Majority of the farmers in the area are Muslim followers where credit utilization is not encouraged.

Table 6: Annual income of the respondents

\begin{tabular}{llllll}
\hline Variable & Obs & Mean & Std. Dev. & Min & Max \\
\hline Total coffee revenue (birr per year) & 247 & 38500.65 & 33989.19 & 4600 & 240,200 \\
Credit used (birr per year) & 247 & 1580.97 & 1968.12 & 0 & 10,000 \\
Off-farm income (birr per year) & 247 & 10117.45 & 11157.3 & 0 & 92,500 \\
\hline
\end{tabular}

Source: Survey result, 2019

\section{Institutional services}

In the study area, majority of the smallholder farmers have access to extension services (about 96\%). About $47 \%$ of the respondents did not utilize credit during the survey year. 
Table 7: Access to institutional services of the respondents

\begin{tabular}{lll}
\hline Variables & Freq. & Percent \\
\hline Access to extension services & & \\
No & 9 & 3.64 \\
Yes & 238 & 96.36 \\
Credit utilization & & \\
No & 117 & 47.37 \\
Yes & 130 & 52.63 \\
Source of credit & 93 & 37.96 \\
Bank & 133 & 54.29 \\
OCSC & 19 & 7.76 \\
Cooperatives & & \\
Access to training on contract farming/ certification & 128 & 51.82 \\
No & 119 & 48.18 \\
Yes & & \\
\hline
\end{tabular}

Source: Survey result, 2019

\section{Comparative analysis}

Table 8 below shows summary statistics for some variables in the data collected. Out of the sample households interviewed, 131 of them were found to be participants in coffee certification while 116 of them were uncertified. On the other hand, 103 of the respondents were coffee contract farming participants while 144 of them were non-participants in coffee contract farming. As shown in the table, there was no significant difference in the mean of age, education level and distance between certified and uncertified coffee producers. Certified farmers had on average, significantly lower total family size compared to the uncertified farmers. Land holding size and farming experience showed significant differences between certified and uncertified farmers.

In terms of age, education level, annual offfarm income and extension contact of households, there was no significant mean difference between certified and uncertified farmers (Table 8). The average ages of certified and uncertified respondents were found to be 44.83 and 46.07 years with the standard deviations of 10.79 and 11.31 respectively.

Table 8: Summary statistics for socio-economic variables

\begin{tabular}{llllll}
\hline Variables & \multicolumn{4}{l}{ Certified $(n=131)$} & \multicolumn{3}{l}{ Uncertified $(n=116)$} \\
Age (years) & Mean & Std. Dev. & Mean & Std. Dev. & T-value \\
\cline { 2 - 6 } Education status & 44.83 & 10.793 & 46.07 & 11.307 & 0.868 \\
Family size & 4.23 & 2.426 & 4.75 & 2.731 & 1.588 \\
Land holding (hectare) & 5.71 & 1.850 & 6.46 & 2.338 & $2.799^{*}$ \\
Experience (years) & 2.35 & 1.055 & 2.70 & 1.458 & $2.212^{*}$ \\
Distance (km) & 24.10 & 10.755 & 27.19 & 12.399 & $2.098^{*}$ \\
Sundry coffee produced (Quintal) & 3.73 & 3.098 & 4.18 & 3.850 & 1.039 \\
Sundry coffee sold (Quintal) & 9.02 & 9.678 & 9.85 & 7.446 & 0.756 \\
Wet cherry produced (Quintal) & 8.63 & 9.812 & 9.56 & 7.500 & 0.826 \\
Wet cherry coffee sold (Quintal) & 7.13 & 6.910 & 7.14 & 5.829 & 0.015 \\
Total coffee revenue (Birr per year) & 6.99 & 6.847 & 7.03 & 5.871 & 0.046 \\
Credit used in birr & 37463.82 & 38471.49 & 39671.55 & 28205.48 & 0.509 \\
Frequency of extension contact & 1648.86 & 2068.718 & 1504.31 & 1853.898 & -0.575 \\
Access to training & 0.78 & 0.417 & 0.72 & 0.449 & -0.989 \\
Off-farm income & 0.49 & 0.502 & 0.48 & 0.519 & 1.222 \\
Consumption (quintal) & 10363.89 & 13500.2 & 9839.14 & 7753.412 & -0.368 \\
\hline Sourc: Survey & 0.95 & 0.642 & 0.89 & 0.490 & -0.759
\end{tabular}

Source: Survey result, 2019

The average family size of sampled respondents was found to be 6.06 years. The minimum and maximum family sizes were found to be 1 and 15, respectively. There was no significant 
mean difference in total family size among certified and uncertified farmers at 5\% significance level (Table 8). The average education level of sampled households was 4.47 years of schooling. The average educational level of certified farmers was 4.23 grades and 4.75 grades for uncertified farmers.

The study also revealed that the mean landholding size of certified farmers was 2.35 hectares, whereas that of uncertified farmers was 2.70 with standard deviation of 1.458 .

To reach to the main road from their home in the study area, it was found that the certified farmers walked on average $3.73 \mathrm{~km}$ with standard deviation of 3.09 while the uncertified farmers took $4.18 \mathrm{~km}$ with a standard deviation of 3.85 . The mean difference in distance from main road between the two groups was not statistically significant.

Average experience of certified respondents in the coffee production was 24.10 years with standard deviation of 10.75. Additionally, the average coffee farming experience of uncertified farmers was 27.19 years with standard deviation of 12.3991 (Table 8).

\section{Determinants of participation in coffee certification}

Table 9 below presents the maximum likelihood estimates and the marginal effects from the Probit regression. Among the independent variables considered five variables, namely, experience in coffee production, education level, family size, access to training and land ownership significantly influenced the probability of participation in coffee certification in the study area.

Education status was significant (at 10\% probability level) and positively related with the participation of coffee certification. The marginal effect revealed that keeping the effect of other variables constant, as the farmers' education level increased by one grade, their probability of participation in coffee certification increased by $2.4 \%$. This suggests that wider education services would boost the participation level of farmers in coffee certification in the study area.

The results also indicated that family size negatively and significantly (at 5\% probability level) influenced coffee certification decision. Keeping other things constant, as farmers' family size increased by one, their probability of participation in coffee certification decreased by $3.6 \%$. This may imply that large family size is related to high consumption of coffee at home and may lead to less participation in coffee certification.

Land size owned is also found to significantly determine participation decision of farmers in coffee certification at $10 \%$ probability level. Keeping other factors constant, as the land holding size of farmers increased by one hectare, the probability of participation in coffee certification increased by $4.8 \%$.

Table 9 : Probit result of determinants of coffee certification participation decision

\begin{tabular}{llllll}
\hline Coffee certification participation & Coef. & Std. Err. & Marginal effects & Std. Err. & P>z \\
\hline Age & -0.003 & 0.008 & -0.001 & 0.003 & 0.736 \\
Sex & 0.137 & 0.209 & 0.055 & 0.083 & 0.511 \\
Education status & 0.059 & 0.035 & $0.024^{*}$ & 0.014 & 0.089 \\
Family size & -0.091 & 0.044 & $-0.036^{* *}$ & 0.017 & 0.037 \\
Land ownership & 0.120 & 0.084 & $0.048^{*}$ & 0.034 & 0.055 \\
Experience & 0.015 & 0.009 & $0.006^{*}$ & 0.003 & 0.086 \\
Distance from market & -0.040 & 0.029 & -0.016 & 0.012 & 0.170 \\
Credit use in birr & 0.001 & 0.001 & 6.920 & 0.001 & 0.753 \\
Extension contact & 0.037 & 0.250 & 0.015 & 0.099 & 0.882 \\
Coffee produced & 0.010 & 0.014 & 0.004 & 0.005 & 0.456 \\
Off farm income & -4.676 & 0.001 & -1.860 & 0.001 & 0.737 \\
Access to training & 0.151 & 0.254 & $0.060^{*}$ & 0.101 & 0.054 \\
Access to transportation & 0.045 & 0.137 & 0.018 & 0.055 & 0.745 \\
cons & 1.601 & & & &
\end{tabular}

$*, * *$ and $* * *$ represent significance at $10 \%, 5 \%$ and $1 \%$ probability levels respectively.

Source: Survey result, 2019

\section{Impact of coffee certification on annual revenue}

To assess the effect of coffee certification on annual net revenue, propensity score matching
(PSM) was applied. For the estimation of propensity scores twelve variables were selected. Propensity scores were estimated for all the 247 sampled farmers. The propensity score of all farmers ranged 
from 0.063 to 0.876 with mean of 0.529 . Among the certified farmers, the predicted propensity score ranges from 0.216 to 0.853 , with a mean of 0.566 while the predicted propensity score of uncertified ranges from 0.063 to 0.876 , with a mean of 0.488 (Table 12). This implies that the common support region for both groups would lie between 0.216 and
0.853, which means households whose estimated propensity scores less than 0.216 and larger than 0.853 were not considered for the matching purpose. Based on this restriction 5 households were dropped from the analysis to estimate the average treatment effect.

Table 10: Summary of estimated propensity scores

\begin{tabular}{lllll}
\hline Groups & Obs & Mean & Min & Max \\
\hline All farmers & 247 & 0.529 & 0.063 & 0.876 \\
Certified & 131 & 0.566 & 0.216 & 0.853 \\
Uncertified & 116 & 0.488 & 0.063 & 0.876 \\
\hline
\end{tabular}

Source: Survey result, 2019

The density distribution of the propensity scores for certified and uncertified farmers is also shown in Figure 1 below. The bottom half of the graph shows the propensity score distribution for the uncertified (control) farmers, while the upper-half of the graph refers to the certified (treated) individuals. The vertical axis indicates the frequency of the propensity score distribution. Visual analysis of the density distribution of the propensity scores confirms that there is a high chance of getting good matches and large number of matched samples as the propensity score distribution is skewed to the right for certified farmers and to the left for the uncertified ones.

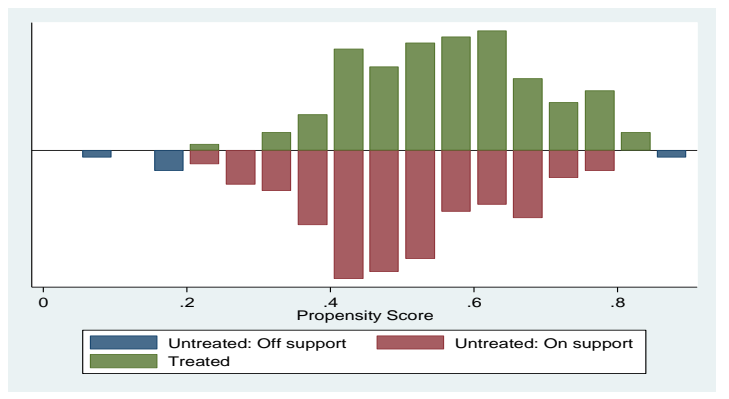

Figure 1: Propensity score histogram
The graph shows that majority of the certified and uncertified farmers were on support indicating that all the individuals within the given range found a suitable match among their counterparts.

Alternative matching algorithms were examined in matching the certified and uncertified households in the common support region depending on three criteria namely: the pseudo- $\mathrm{R}^{2}$, balancing test, and matched sample size. A matching algorithm which bears a low pseudo- $\mathrm{R}^{2}$ value, balances all explanatory variables (insignificant mean differences between the two groups), and results in large matched sample size is appropriate.

The low pseudo- $\mathrm{R}^{2}$ and the insignificant likelihood ratio tests support that both groups have the same distribution in covariates after matching (Table 11). These show that the matching procedure is capable to balance the characteristics in the certified and the matched uncertified groups. Therefore, the results can be used to evaluate the effect of coffee certification participation among households having similar observed characteristics.

Table 11: Chi2 test for variables' significance

\begin{tabular}{llll}
\hline Sample & Pseudo R2 & LR ch2 & P>ch2 \\
\hline Unmatched & 0.14 & 5.12 & 0.973 \\
Matched & 0.005 & 1.89 & 1.00 \\
\hline
\end{tabular}

Source: Survey estimation result, 2019

According to the indicators of matching parameters, nearest neighbor (3), was selected to be the best matching algorithm for the data in this study bearing the lowest pseudo- $\mathrm{R}^{2}$ of 0.0590 and matched sample size of 247. 
Table 12: Performance of matching algorithms

\begin{tabular}{|c|c|c|c|}
\hline \multirow[b]{2}{*}{ Matching algorithm } & \multicolumn{3}{|l|}{ Performance parameters } \\
\hline & $\begin{array}{l}\text { No. of insignificant } \\
\text { variables }\end{array}$ & Pseudo R2 & Matched sample size \\
\hline $\mathrm{NN}(1)$ & 10 & 0.059 & 247 \\
\hline $\mathrm{NN}(2)$ & 10 & 0.059 & 247 \\
\hline $\mathbf{N N}(3)$ & 10 & 0.059 & 247 \\
\hline $\mathrm{NN}(4)$ & 10 & 0.059 & 242 \\
\hline Caliper (0.01) & 10 & 0.059 & 241 \\
\hline Caliper (0.1) & 10 & 0.059 & 247 \\
\hline Caliper (0.25) & 10 & 0.059 & 247 \\
\hline Caliper (0.5) & 10 & 0.059 & 247 \\
\hline Band width of (0.01) & 10 & 0.059 & 242 \\
\hline Band width of (0.1) & 10 & 0.059 & 247 \\
\hline Band width of $(0.25)$ & 10 & 0.059 & 247 \\
\hline Band width of $(0.5)$ & 10 & 0.059 & 247 \\
\hline
\end{tabular}

Source: Survey estimation result, 2019

Table 12 also shows the results of the covariate-balancing test to check that both groups had the same distribution in variables selected after matching. It presents the means of variables, their $\mathrm{t}$ test of differences in means as well as the percentage bias before and after matching. For all variables, the matched sample means were almost similar for both the certified and the uncertified, which was not the case before matching.

The effect of participating in coffee certification on coffee annual revenue was estimated using the nearest neighbor matching (NNM) (Table15). The outcome variable was annual revenue from coffee in ETB. The effect of participation is shown by the difference in ATT between the certified and uncertified coffee producers. The results indicated that, participating in coffee certification has a positive and significant effect on the annual revenue of the households. The estimates for the annual household revenue earned from coffee certification participation are 2902 ETB.

Table 13: The effect of coffee certification participation

\begin{tabular}{llllll}
\hline Matching algorithms & Sample & Treated & Control & Difference & T-stat \\
\hline Nearest Neighbor & Unmatched & 39671.5517 & 37463.8168 & 2207.73493 & 0.50 \\
& ATT & 37463.8168 & 34561.3232 & $\mathbf{2 9 0 2 . 4 9 3 6 4}$ & 0.60 \\
& ATU & 39946.8468 & 34681.1411 & 5265.70571 & \\
& ATE & & & 3162.54453 & \\
\hline
\end{tabular}

Source: Survey result, 2019

The results indicated that participation in coffee certification has a significant positive effect on annual household coffee revenue.

The results indicated that participation in coffee certification has a significant positive effect on annual household coffee revenue.

\section{Sensitivity Analysis for Hidden Bias}

The propensity score matching model applied in this study assumes the differences between the participants and the non-participants is just because they differ in observable variables in the data set that is the conditional independence assumption. However if the two comparison groups differ in unobservable features the conclusion of the positive effect of participation in coffee certification and contract farming on the revenue from coffee may be doubtful. The aim of the sensitivity analysis is to check whether implications about participation effects may be altered by unobserved variables.

Since it is not possible to estimate the magnitude of selection bias while using PSM, Aakvix (2001) suggests the use of Rosenbaum bounds (rbounds) test that tests the null hypothesis that there is no change on the treatment effect for different values of unobserved selection bias. This study therefore conducted the sensitivity analysis for the presence of hidden bias using the Rosenbaum bounds (rbounds test) in STATA 13. This sensitivity test shows how hidden biases might alter inferences 
about treatment effects without indicating whether biases are present or what magnitudes are acceptable.

In order to check for unobservable biases, using Rosenbaum Bounding approach sensitivity analysis was performed on the computed outcome variable. The results showed that the effect of coffee certification and contract farming participation does not change, even though participant and nonparticipant households were allowed to differ in their propensity score of being treated up to $203 \%$ $(\mathbf{e} \gamma=2.03)$ in terms of unobserved covariates.

Thus, it is possible to conclude that the impact estimates (ATT) are insensitive to unobserved selection bias, being the effects of coffee certification and contract farming participation.

\section{CONCLUSIONS}

According to econometric results, experience in coffee production, education level, family size, access to training and land ownership significantly influenced the probability of participation in coffee certification. The propensity score matching estimation results as given by average treatment effect on the treated (ATT) showed that coffee certification has a positive significant effect on farmers' annual revenue. The estimates for the average annual household revenue earned from participation in coffee certification were 2902 ETB. This result indicates that participation in coffee certification significantly improved farmers' annual revenue in comparison with selling their product at the open market.

The price is determined through negotiation based on the market price of coffee. Farmers can get from 15 to $20 \%$ higher price when they fulfill the quality requirements as described in the agreement and dividend from their certification participation.

Based on the findings of this study, understanding of significant factors in this study would contribute to the design of appropriate strategies to achieve sustainable agricultural marketing channels that link smallholder farmers with agricultural processors like coffee processors.

Policies aiming at expansion of coffee certification in the study area should consider a way of improving smallholders' access to market information so that they are aware of coffee certification and other modern marketing systems.

Any projects or NGOs dealing with agricultural value chains through coffee certification should take into account that access to market information has a positive and significant influence on farmers' participation in modern marketing.

Although it was indicated that participation in coffee certification positively affected the annual revenue, farmers' awareness of coffee certification is very low. This can be improved through organizing experience sharing programs, preparing field visits and workshops by concerned governmental officials.

To increase farmers' awareness about better marketing systems, a strong extension service and trainings are important. This study indicated that the existing extension service and training have a positive effect on coffee certification participation and on annual revenue. Strengthening the extension service can help to increase marketing performance and coffee production. In this regard, improving the extension requires, designing and providing specific training on production and marketing systems as well as close monitoring system by concerned processing companies and unions.

Policies aiming to improve the income of smallholders in the study area should also consider credit access of the farmers. Both government and NGOs' financial institutions should focus on the improvement of these credit services.

This study focused on some aspects of coffee certification, and its effect on annual revenue of coffee producers. However, many aspects of coffee certification like technical efficiency need further research. Given the limited scope of the study, this research suggests that further research should be undertaken in order to clearly understand the nature of certification in different contexts.

$\begin{array}{ll}\text { Abbreviations } \\ \text { ATE } & \text { Average Treatment Effects } \\ \text { ATT } & \text { Average Treatment on the Treated } \\ \text { ATU } & \text { Average Treatment on Untreated } \\ \text { CSA } & \text { Central Statistical Agency } \\ \text { ETB } & \text { Ethiopian Birr } \\ \text { FGD } & \text { Focus Group Discussion } \\ \text { GAIN } & \text { Global Agricultural Information } \\ & \text { Network } \\ \text { GDN } & \text { Global Development Network } \\ \text { GTP } & \text { Growth Transformation Plan } \\ \text { KII } & \text { Key Informant Interview } \\ \text { NGO } & \text { Non-Governmental Organization } \\ \text { OCSC } & \text { Oromia Credit and Saving Share } \\ & \text { Company } \\ \text { PSM } & \text { Propensity Score Matching } \\ \text { SPSS } & \text { Statistical Package for Social Sciences } \\ \text { TLU } & \text { Tropical Livestock Unit } \\ \text { UNDD } & \text { Unions of National for Democracy and } \\ & \text { Development } \\ \text { USD } & \text { United States Dollar }\end{array}$

\section{ACKNOWLEDGEMENTS}

We are grateful to the Japanese Award for an outstanding research (Global Development Network) Project, for their financial, technical 
training, and all other supports for the success of this study. We thank Professor Mengistu Ketema for mentoring the whole processes of the study. Finally we highly thank Jimma University College of agriculture and veterinary medicine for hosting this study and facilitations through financial services.

\section{REFERENCES}

Abadie, A. and G.W. Imbens, 2004. Large Sample Properties of Matching Estimators for Average Treatment Effects. Econometrica, 74:235- 67.

Abdul-Jalil, M.A., 2015. Determinants of access to credit and its impact on household food security in Karaga district of the Northern region of Ghana (Doctoral dissertation).

Anderson, K. Mbuba, Eric K. Bett, Charles Ndenga and Newton Nyairo, 2018. Analysis of factors influencing microfinance credit uptake among smallholder coffee farmers in Tharaka Nithi county, Kenya. International Journal of Agricultural Extension and Rural Development ISSN 3254-5428, 6 (3) :622-627,

Baker. J. 2000. Evaluating the Impact of Development Projects on Poverty A Handbook for Practitioners. The World Bank Washington, D.C.

Becker, S. and A. Ichino, 2002. Estimation of average treatment effects based on propensity scores. The Stata Journal 2(4): $358-377$.

Berhanu Lakew 2003, Prospects for Export Diversification in Ethiopia, NBE Staff Working Paper ERD/SWP/007/2003

Caliendo, M. and Kopeinig, S. 2008. Some practical guidance for the implementation of propensity score matching. Journal of Economic Surveys, Vol. 22, (2008), 31-72.

CSA, 2017. Report on Area and production of Major Crops. The Federal Democratic Republic of Ethiopia; Central Statistics Agency Agricultural Sample Survey for 2016/2017 Addis Ababa, Ethiopia., 1, 1-125

CSA, 2019. Report on Area and Production of Major Crops (Private Peasant Holdings, Meher Season) for 2018/19. Central Statistical Agency (CSA), Statistical Bulletin 589, Volume I, Addis Ababa, Ethiopia.
Djoumessi, Y.F., Kamdem, C.B., Afari-sefa, V. and Bidogeza, J.C., 2018. Determinants of Smallholder Vegetable Farmers Credit Access and Demand in Southwest region, Cameroon. Economics Bulletin, 38(2) : 1231-1240.

Dehejia, R. and Wahba, S., 2002. Propensity Score Matching Methods for Non- Experimental

GAIN Report, 2014. Coffee Annual report, Ethiopia.

Grote, U. 2009. Environmental Labeling. Protected Geographical Indications and the Interests of Developing Countries. The Estey Centre Journal of International Law and Trade Policy 10(1), pp.94-110.

Grote, U., Basu, A.K. and Chau, N. (eds.) 2007. New Frontiers in Environmental and Social Labeling.Physica Publisher, Heidelberg.

Heckman, J. 1998. Sample Selection Bias as a Specification error. Econometrica, Volume 47, Issue 1, 153-162.

ICO. 2019. Growing Prosperity - Economic viability as the catalyst for a sustainable coffee sector, London.

Kasente, D. 2012. Fair Trade and organic certification in value chains: lessons from a gender analysis from coffee exporting in Uganda. Gender and Development (20).

Kifle, D., Tadesse, Y., Belay, S. and Yusuf, J., 2013. Determinants of women's participation in microfinance services: empirical evidence from Rural Dire Dawa, Ethiopia. African Journal of Agricultural Economics and Rural Development, 1(1):1-7.

Orebiyi, J.S; Henri-Ukoha, A, Ben-Chendo N.G, Tasie C.M and Ekine D.I 2012: Determinants of credit supplied by IFAD to rural farmers beneficiaries in Rivers State, Nigeria. International Journal of Agricultural Economics, Management and Development 2;84-76.

Ponte, S. 2004. Standards and Sustainability in the Coffee Sector: A Global Value Chain Approach. Winnipeg, International Institute for Sustainable Development.

Ravallion, 2005. The World Bank Research Program, 2005-2007: Abstracts of Current Studies

Rosenbaum, P.R., and D.B. Rubin, 1983.The Central Role of the Propensity Score in 
Observational Studies for Causal Effects. Biometrika, 70 (1): 41-45.

Roberts, L.C., Otieno, D.J. and Nyikal, R.A., 2017. An analysis of determinants of access to and use of credit by smallholder farmers in Suakoko District, Liberia. African Journal of Agricultural Research, 12(24) :.20932100.

Ruben and Fort, 2012. The Impact of Fair Trade Certification for Coffee Farmers in Peru

Samuel Elias, Isah Musa Ahmad, and Patil B.L., 2015.The Determinants of access to Agricultural credit for small and Marginal Farmers' in Dharwad district, Karnataka, India. Research Journal of Agriculture and Forestry Science. 3(5):1-5.

Samuel S., 2010. Credit Default Risk and its Determinants of Microfinance Industry in Ethiopia.

Saqib, S.E., Kuwornu, J.K., Panezia, S. and Ali, U., 2018. Factors determining subsistence farmers' access to agricultural credit in flood-prone areas of Pakistan. Kasetsart Journal of Social Sciences, 39(2): 262-268.
Smith, J. and Todd, P., 2005. Does Matching Overcome LaLonde's Critique of Nonexperimental Estimators? Journal of Econometrics, 125(1-2): 305-353.

Tang, S., Guan, Z., and Jin, S., 2010. Formal and informal credit markets and rural credit demand in China. Paper presented at the Agricultural and Applied Economics Association. AAEA, CAES and WAEA joint annual meeting, Denvere, Colorado, July 25-27, 2010.

UNDP (United Nation Development Programme), 2009. African Economic. Website Outlook.www.african economic outlook.org.

Vavilov, N.I. 1951. The Origin, Variation, Immunity and Breeding of Cultivated Plants (Translated by S. K. Chestitee). Chronica Botonica, 13, 1-366. 